\section{The relationship between brand Facebook page characteristics, perceived value, and customer engagement behavior: An application of Stimulus-Organism-Response (S-O-R)}

\author{
Wajeeha Aslam ${ }^{1}$ \\ Iviane Ramos de Luna ${ }^{2}$
}

\begin{abstract}
Purpose - With the advancement of technology and increased use of social media, brands have become part of the virtual world and try to grab customers' attention. Brand pages enable the consumer to voluntarily participate in providing feedback and ideas and to collaborate with others. This adds value to the firm. This research explores which characteristics help clothing brands to influence consumers into responding in the form of feedback, collaboration, and mobilization.
\end{abstract}

Design/methodology/approach - Data were collected from 250 respondents who had purchased their favorite clothing brand in the last four months, using five-point Likert scale questionnaires. Partial least squares structural equation modeling (PLS-SEM) was used to analyze the data.

Findings - The results indicate that content quality leads to brand learning values and hedonic values. Customer contact quality only affects brand learning value. Both hedonic and brand learning values induce customer engagement behaviors.

Originality/value - This study provides useful insights for clothing brand webpage managers related to customer engagement in social media. The study extends the concept of customer engagement behavior (CEB) by incorporating consumer "mobilizing behavior" as an additional element of CEB.

Keywords - Social Media, Content Quality, Hedonic Values, Customer Engagement Behavior, S-O-R

1. IQRA University, Department of Business Administration, Karachi - Pakistan

2. Universitat Oberta de Catalunya, Department of Economic and Business Studies, Barcelona - Spain

How to cite:

Aslam, Wajeeha, Ramos de Luna, Iviane (2021). The relationship between brand Facebook page characteristics, perceived value, and customer engagement behavior: An application of Stimulus-Organism-Response (S-O-R). Revista Brasileira de Gestão de Negócios, 23(1), p.43-62.
Received on:

06/17/2020

Approved on:

09/08/2020

Responsible Editor:

Francisco José Liébana

\section{Evaluation process:}

Double Blind Review

\section{Reviewers:}

Rocío Aguilar Illescas; Rafael AnayaSánchez.

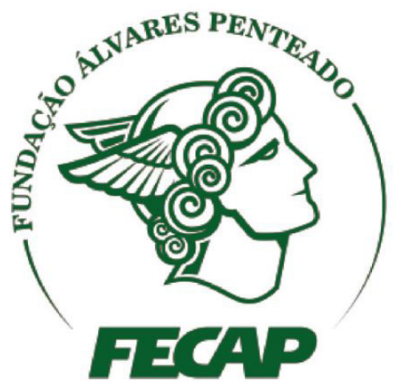

Revista Brasileira de Gestáo de Negócios

https://doi.org/10.7819/rbgn.v23i1.4092 


\section{Introduction}

Globally, the number of internet users surpassed 4.54 billion in January 2020, i.e. 59\% of the world population (Statista, 2020), and among them, 92\% of users access the internet through mobile devices (We are social, 2020). Moreover, the use of social media has multiplied severalfold, with the global number of users reaching 3.8 billion (We are social, 2020).

Due to the greater importance of social media, brands are now substantially investing in it to better engage with their customers (Carlson, Rahman, Voola, \& Vries, 2018; Hamilton, Kaltcheva, \& Rohm, 2016; Kao, Yang, Wu, \& Cheng, 2016; Uncles \& Ngo, 2017).

By exploiting social media, firms can easily interact with customers as it enables two-way communication and encourages valuable customer participation to a greater extent than in the past (Hudson, Huang, Roth, \& Madden, 2016; Mega Marketing, 2018). It is a modern mode of communication that accommodates customers' interactions, collaboration, knowledge sharing, and information related to their preferences, in order to support brands (Alexander, Jaakkola, Brodie, \& Hollebeek, 2015; Carlson et al., 2018; Gruner, Homburg, \& Lukas, 2014; Tuten, 2008; Zhu, Chang, \& Luo, 2016). Consumers on social media who share information and ideas are considered as active donors of information rather than passive receivers (Hollebeek, Srivastava, \& Chen, 2016; Stewart \& Pavlou, 2002).

In past studies, researchers have considered online platforms as "engagement platforms" where people exchange resources and co-create value (Breidbach, Brodie, \& Hollebeek, 2014; Ramaswamy, 2009). From this perspective, customer engagement behavior (CEB) examines customer behavior towards brands that goes beyond purchases and arises from motivational drivers that add value to firms (Groeger, Moroko, \& Hollebeek, 2016; Van Doorn et al., 2010). For example, customer interaction with fellow brand users results in the generation of useful information related to the brand, shared and spread by the customers (Daugherty, Eastin, \& Bright, 2008). Here, a customer becomes a focal person by sharing brand experiences on social media (Vries \& Carlson, 2014). Positive customer reviews often result in an increased perception of credibility of a particular product in the minds of the targeted customers and help generate huge customer traffic (Roy, 2018).
The increasing interaction of consumers on social media raises questions about what motivates customer engagement behavior (CEB) on brand pages. Despite brands being able to extract value by engaging customers on social media networks, they appear to shy away from this, which is largely due to their lack of knowledge on how to do it (Carlson et al., 2018; Roberts \& Piller, 2016). Therefore, there is a pressing need to understand what stimulates engagement behavior in a social environment to help brands enhance their value proposition. It is therefore necessary to understand the stimulating factors that firms must provide to encourage consumers to voluntarily participate in brand communities and brand pages.

The clothing sector is one that has most explored the benefits of communication on social platforms. It is considered one of the most outstanding sectors worldwide as it has seen constant growth due to its evolutionary nature, in which it constantly presents new trends (Casaló, Flavián \& Ibañez-Sánchez, in press; Kim, Ko, Xu, \& Han, 2012). The global apparel market is forecasted to be worth approximately 1.52 trillion dollars by the end of 2020 (O'Connell, 2020).

Social networks have played an important role in consumer interest in this sector, as well as in the companies operating in it, since they provide a potential channel for communication with consumers. Consequently, researchers assuming different perspectives have developed studies to measure the impact of social networks on consumer behavior and how this affects clothing brands and companies' development (Ananda, Hernández-García, Acquila-Natale, \& Lamberti, 2019; Barreda, Bilgihan, Nusair, \& Okumus, 2015; Casaló et al., in press; Cengiz, 2017; Chiu, Huang, \& Yen, 2010; Kim \& Ko, 2012; Kim et al., 2012; Thongmak, 2015).

Unlike past studies in this field, this study aims to contribute to expanding the knowledge on consumer engagement behavior on clothing brand pages in online social networks based on the concepts provided by Carlson et al. (2018), Groeger et al. (2016), Jaakkola and Alaxendar (2014), Van Doorn et al. (2010), and Verleye, Gemmel, and Rangarajan (2014). It examines three specific forms of CEB as antecedents of customer engagement behavior: (1) feedback intention, which is related to the voluntary sharing of opinions by consumers about brand experiences; (2) collaboration intention, which is related to helping, supporting, or exchanging information with other consumers in the brand community, also in a voluntary manner; and (3) mobilizing intention, which 
refers to the power that customers' contributions have to mobilize other customers' behaviors towards the brand.

The choice of these variables for this research is based on the results of other studies (Carlson et al., 2018; Groeger et al., 2016; Roy, Balaji, Soutar, Lassar, \& Roy, 2018) that highlight the importance of voluntary contributions from customers, such as feedback, collaboration, and mobilization, for the development of brands when they are properly managed.

In addition, this study uses Stimulus-OrganismResponse (S-O-R) theory to link online service characteristics to CEB intentions. The purpose of using S-O-R theory is that it conceptualizes consumers' responses to consumption environments, allowing researchers to better understand the complicated process behind consumers' responses and decisions (Chen \& Yao, 2018; Liu, Li, \& Hu, 2013; Verhagen \& van Dolen, 2011). S-O-R theory is widely used by researchers in determining consumer behavior in online contexts (Arif, Aslam, \& Siddiqui, 2020; Bui \& Kemp, 2013; Dabbous \& Barakat, 2020; Ha \& Im, 2012; Park, Han, \& Park, 2013; Peng \& Kim, 2014). More specifically, the current study treats content quality and customer contact quality as stimuli, brand learning value and hedonic value as reflections of emotional reactions (organism), and CEB as a response.

In summary, this research study examines CEB in the context of clothing brand social media pages. The main reason for selecting clothing brand pages are: (1) past studies and reports have confirmed that the fashion industry is the fastest growing one on social media (AlphaPro, 2018; Arif et al., 2020; Aslam, Ham, \& Farhat, 2018); (2) the majority of users buy clothing brands online (Business Recorder, 2019; Facebook for Business, 2017); and (3) to our knowledge, there are very few empirical studies that investigate the influence of CEB in the context of clothing brand social media pages and, therefore, it is important to expand the knowledge on this topic in different contexts. This study benefits firms by providing insights on the triggers of engagement behaviors, namely feedback, collaboration, and mobilizing intention.

This paper is structured as follows. Initially, we review the literature concerning the main constructs of the research. Next, we propose hypotheses and develop a research model. After that, we discuss the research method and describe the research findings. Finally, we present the discussion, followed by the implications and limitations.

\section{Theoretical Background}

\section{I S-O-R theory}

S-O-R theory explains how an environment influences an individual's perception and behavior. The environmental aspects are considered as stimuli (S), which have an impact on humans' emotions, i.e. the organism $(\mathrm{O})$, which further leads to the development of behavioral responses (R) (Mehrabian \& Russell, 1974). Many scholars have investigated and supported this theory, such as Peng and Kim (2014) for online shopping behavior, CacheroMartínez and Vázquez-Casielles (2017) in the retailing context to see how a positive environment stimulates satisfaction, Arif et al. (2020) to identify the impact of user-generated content on consumer behavior, Liu, Guo, Ye, and Liang (2016) to measure the impact of home page aesthetics on satisfaction, and Aslam et al. (2018) used it to evaluate the impact of electronic word-of-mouth on purchase intention. Baker, Grewal, and Parasuraman (1994) used this theory in the retail shopping context and their findings confirmed that the store environment influences the internal state of the consumer, which in turn drives the latter towards the store. Likewise, Dabbous and Barkat (2020) explained the influence of social media on brand awareness and purchase intention by using S-O-R theory.

As far as online platforms are considered, the environmental stimuli here refer to the attributes of the platforms in terms of the design or appearance of the webpages (Eroglu, Machleit, \& Davis, 2003). The organism part concerns internal characteristics, including customers' judgments, perceptions, emotions, and experiences, which lie between stimuli and customer responses (Jiang, Chan, Tan, \& Chua, 2010). The responses are the behaviors of customers that compel them to approach or ignore a brand (Eroglu et al., 2003). Islam and Rehman (2017) also used S-O-R theory to examine customer engagement behavior in an online brand community and considered information quality, system quality, virtual interactivity, and rewards as stimuli, customer engagement as the organism, and loyalty as a response.

S-O-R theory is used in this study to determine customer engagement behaviors for two reasons. Firstly, previous studies have used S-O-R theory extensively to predict customer engagement behaviors on social media (Carlson et al., 2018; Zhang, Lu, Wang, \& Wu, 2015) and they have provided evidence that S-O-R explains customers' responses to environmental stimuli. 
Secondly, it helps to predict the role of website features and customer behavior on social media. S-O-R theory provides an organized path via which to study the effects of the website characteristics of social media on customers' judgments about the perceived benefits they obtain (internal organisms), which ultimately lead to them participating and collaborating in brand-related activities (Zhang et al., 2015).

\section{I.I Environmental stimuli (S)}

In an online environment, brands communicate through brand pages as this mode elicits interactivity between brands and customers (Jahn \& Kunz, 2012; Zhang, Lu, Gupta, \& Zhao, 2014). Previous research has shown that web-based features promote engagement behaviors (Carlson et al., 2018) and has identified a few pivotal web-based features, among which content quality has been given great importance. In contrast, few studies have considered the element of customer contact quality, even though social media offers contact advantages to its users. Therefore, in this study these two important web-based features are considered, i.e. content quality (reliability of available information) and contact quality (how information is made available to customers).

Past studies have stated that on brand pages customers seek up-to-date information (Dholakia, Blazevic, Wiertz, \& Algesheimer, 2009; Shi, Chen, \& Chow, 2016) and the available content is evaluated in terms of various aspects, such as timeliness, adequacy, relevance, and completeness (Arif et al., 2020; Carlson et al., 2018). Content that is interesting and appealing to the audience attracts customers' attention to the brand (Berger \& Milkman, 2012) and raises their level of trust (Cvijikj \& Michahelles, 2011). In addition, content quality works as a stimulus and determines online customer behavior (Nambisan \& Baron, 2009; O'Cass \& Carlson, 2012). Gummerus, Liljander, Weman, and Pihlström (2012) also argue that consumers feel worthy when they get useful information on brand pages.

Other important elements on brand pages include how efficiently and effectively the firm interacts with its customers (Carlson et al., 2018). Therefore, customer contact quality is another important stimulus that provides customers with ease of use, fun, and entertainment, and serves as a source of information sharing, in contrast to other means of communication (Gironda \& Korgaonkar, 2014). O'Cass and Carlson (2012) refer to contact quality as effective and efficient interaction between consumers and brands through electronic resources instead of traditional ones. In the age of digitalization, not only firms but also customers strive to remain up-to-date, access available information, and answer their queries using the platform of social media (Carlson et al., 2018).

\subsubsection{Organism (O)}

$\mathrm{S}-\mathrm{O}-\mathrm{R}$ theory further explains the environmental stimuli provided by web-based characteristics that affect customers' perceived value, which comprises the organism part of the model. The organism can be a cognitive and emotional aspect in the consumption experience. In the case of web-based services, the stimuli provided by the brand page affect the customers' online experience and deliver a variety of benefits to the followers (Carlson, Rahman, Rosenberger, \& Holzmüller, 2016).

Kohler, Fueller, Matzler, Stieger, and Füller (2011) and Nambisan and Nambisan (2008) described three types of experiences in the online environment, namely pragmatic, sociality, and hedonic experiences. For brand social media pages, Zhang et al. (2015) identified brandlearning value as pragmatic; this refers to the customer experience in realizing cognitive benefits. Their work identifies that brand-learning value and hedonic value highly impact customer participation in brand social media pages. Brand-learning value and hedonic value determine customer engagement and serve as core consumption values on brand pages (Carlson et al., 2018). Considering the importance of these two elements, this study incorporates brand-learning value and hedonic value as an organism.

Customers view brand pages as learning platforms and other members of the page and the brand itself are capable of giving beneficial suggestions about the brand features or usage, which further enhance the process of interaction among the members (Shi et al., 2016). Brand learning value can be defined as the utility obtained by customers from the cognitive benefits provided by the brand page that concern gaining brand-related information (Zhang et al., 2015).

Hedonic values refer to the entertainment and enjoyment that a customer experiences while using or engaging with the brand page (Carlson et al., 2018). Fun and entertainment are the key features of social media, which delivers pleasurable experiences to users (Arif et al., 2020). The environment of a brand page provides customers with a source of interaction, pleasure, and cognitive 
benefits, which are the result of the collaborative and lively environment of social media (Zhang et al., 2015). In this study, both aspects of the experience, hedonic and cognitive, are considered as an organism i.e. hedonic value and brand-learning value, respectively.

\section{I.3 Response (R)}

Customer engagement behavior (CEB) is a phenomenon that has emerged from resource exchange theory and the affect theory of social exchange, according to which customers deliberately take part in voluntary behaviors, and organizations need to adopt certain practices in order to address such behaviors (Verleye et al., 2014). CEB may evolve either customer-to-firm interactions (resulting in cooperation, compliance, and feedback) or customer-to-customer interactions (resulting in collaboration and positive WOM) (Verleye et al., 2014).

In light of resource exchange theory, CEBs are considered as customers' feelings of 'love' towards the firm, which result from the firm's investment in the customer, going beyond just financial benefits (Bettencourt, 1997). The affect theory of social exchange states that social exchanges are based on the level of customer affect. The greater the level of customer affect towards the firm, that is, the positive attitude towards the firm, the greater the manifestation of customer engagement behaviors (including providing feedback and assisting other customers) (Verleye et al., 2014). Consumers who have positive feelings towards a brand are likely to contribute by giving feedback and helping other customers. Carlson et al. (2018) addressed two forms of CEB (feedback and collaboration) on social media and emphasized increasing the richness of CEB by adding other aspects. Three forms of CEB intentions were discussed, namely, feedback, collaboration, and mobilizing intentions.

The earlier studies indicate that feedback and collaboration behaviors are forms of innovation-based customer motives (Van Doorn et al., 2010). Collaboration intentions refer to customers' provision of support, assistance, and information to others voluntarily, via the brand page, enabling a better brand experience (Carlson et al., 2018). Mobilizing behavior is the dimension of CEB analyzed by Jaakkola and Alaxendar (2014), which refers to customer contributions of resources such as relationships and time, to mobilize other stakeholders' actions towards the focal firm. Thus, brand social media pages provide customers with a forum where they can share their views and help generate WOM intentions.

\subsection{Hypotheses development}

\subsection{Content quality and brand learning value}

Content quality refers to the customers' viewpoint about the information available on the brand page related to the brand and products offered. This may include the authenticity, relevance, and comprehensiveness of the information (Carlson et al., 2018; Dabbous \& Barakat, 2020; Shi et al., 2016).

Content quality is defined as useful information that adds value and is considered meaningful by the target audience (Arif et al., 2020; Gummerus et al., 2012). Information available on brand pages enhances customers' learning about the brand (Carlson et al., 2018; Ho \& Wang, 2015) and increases brand awareness (Dabbous \& Barakat, 2020). Hamilton et al. (2016) stated that brand learning is enhanced by searching for information related to the brand on brand pages. The participation of new customers may by triggered and motivated by the content available on the brand page, improving their learning and strengthening their relationship with the brand (Kim \& Johnson, 2016). Therefore, webpages that deliver highquality information enable customers to increase their brand-related knowledge, enabling them to make buying decisions with ease (Ahn, Ryu, \& Han, 2004).

Based on the above discussion, we propose that the perceived usefulness of the content and information on brand pages may lead to the enhancement and enrichment of customers' perceived values, such as brand learning value.

$\mathrm{H}_{1}$ : Content quality has a positive influence on brand learning value.

\subsubsection{Content quality and hedonic value}

A variety of studies have concluded that webbased features, namely color, design, and images, have a positive impact on customers' values (e.g. pleasure) and on perceptions such as perceived information quality (Eroglu et al., 2003; Ha \& Im, 2012; Park, Stoel, \& Lennon, 2008). Additionally, task-relevant information helps to induce enjoyment in customers by reducing curiosity and making them feel satisfied (Muniz \& O'Guinn, 2001). Therefore, websites that provide high-quality information 
provide a sense of enjoyment and pleasant experiences (Ahn et al., 2004).

Carlson et al. (2018) stated that useful and effective communication by a brand develops a sense of belonging to the brand page, which brings enjoyment. Studies have confirmed that sometimes online shoppers seek up-to-date and product-related information for the purposes of enjoyment (Eastman, Iyer, \& Randall, 2009; Kim, Galliers, Shin, Ryoo, \& Kim, 2012; Nicolaou \& McKnight 2006; Sorce, Perotti, \& Widrick, 2005). Online posts related to favorite clothing brands bring joy and pleasure (Arif et al., 2020). Dabbous and Barakat (2020) also confirm the significant impact of content quality on hedonic motivation.

Based on the above, we propose that the perceived usefulness of content and information on brand pages may lead to the enhancement and enrichment of customers' perceived values, such as fun and entertainment values.

$\mathrm{H}_{2}$ : Content quality has a positive influence on hedonic value.

\subsubsection{Customer contact quality and brand learning value}

The term customer contact quality means the relative benefit obtained by the customer from using a brand page in terms of ease and information availability as compared to other means of communication (Gironda \& Korgaonkar, 2014). For retail websites, the term can further be modified to mean efficient and effective communication between a firm and customers through a webpage as compared to the other means of contact (O'Cass \& Carlson, 2012). In the past, when there was no marketing through social media, brands faced difficulties in delivering timely advertising communication to their audiences. But now, due to the availability of social media platforms, brands post their communications, such as sale offers, discounts, new product information, etc., quite easily and in a timely manner. In other words, the presence of a brand on social media offers better contact quality. Research shows that brand pages serve as a better medium for customer contact quality as compared to other resources. Webpages are not only convenient means of collecting information, but they also allow customers to share their views with others through comments and reviews and provide knowledge related to brands (Carlson et al., 2018). If the information displayed on a webpage is sufficient, up-to-date, and relevant, it helps to enhance the perceptions of value related to ease, speed, awareness, and entertainment (Arif et al., 2020; Tsao, Hsieh, \& Lin, 2016). One of the greatest benefits of the aforementioned interactions is that firms can engage their customers emotionally (Bilgihan, Kandampully, \& Zhang, 2016).

Due to the high level of customer contact quality on brand social media pages, customers are provided with opportunities such as acquiring adequate information about a brand (Carlson et al., 2018). This enhances their awareness about the brand. Based on the above discussion, we can conclude that customer contact quality on brand pages delivers learning value. Thus, the following can be hypothesized:

$\mathrm{H}_{3}$ : Customer contact quality has a positive influence on brand learning value.

\subsubsection{Customer contact quality and bedonic value}

Liu and Xiao (2008) stated that customers are generally impatient about waiting to access data. Hence, the availability of the information related to brands on webpages brings an element of enjoyment and excitement (Bridges \& Florsheim, 2008; Kim et al., 2012; Lu \& Su, 2009; Overby \& Lee, 2006). Websites that provide quick access to information increase the pleasure of virtual buying (Pebrianti, 2016).

People also navigate information on online stores because they enjoy doing so (Argyris, Muqaddam, \& Liang, 2019; Koufaris, 2002; Kwak, Choi, \& Lee, 2014). Hence, customer contact quality benefits customers by providing information related to brands and it excites them.

Therefore, the following can be stated:

$\mathrm{H}_{4}$ : Customer contact quality has a positive influence on hedonic value.

\subsubsection{Customer perceived value and CEB intentions}

In this discussion, a link is established between customer perceived value and the development of CEB intentions.

This study examines three specific forms of CEB intention with a reflective construct composed of feedback, collaboration, and mobilization. Feedback intentions are related to customers' behavior in the delivery of responses, which may be solicited or unsolicited, comprising their feelings about their experiences with the brand (Verleye et al., 
2014). Collaboration intentions are related to customers voluntarily providing support, assistance, and information, through brand pages, enabling a better brand experience (Carlson et al., 2018). Mobilizing intentions are basically the convincing behaviors that consumers use with others to persuade them to buy an offering (Roy et al., 2018). Mobilizing refers to the behavior of customers that enables them to contribute their time and develop relationships and hence mobilize other customers' behaviors towards a company (Jaakkola \& Alexander, 2014).

\subsubsection{Brand learning value and CEB intentions}

Brand learning value relates to the usage of the cognitive benefits offered by a brand page, which includes the obtainment of brand-related information from the page (Zhang et al., 2015). Brand learning value is the additional value gained within the domain of productrelated knowledge and information regarding usage and other attributes. Learning and enhancing one's knowledge is a goal that can be adequately fulfilled by a social media platform, because it provides its users with the opportunity to share their ideas and experiences, ask questions, and gain feedback from other users on the page and even from the brand itself (Zaglia, 2013).

The increased quality of information available on social media platforms provides a better understanding of brands, resulting in good decision-making (Arif et al., 2020; Barreda et al., 2015; Zhang \& Watts, 2008). Consumers who have gained knowledge related to brands remain engaged and offer help to others (Dholakia et al., 2009). If online customers have the perception that the information quality on a webpage is very high, it not only increases their learning about the brand but also generates positive WOM about the brand and leads to customer satisfaction (Ha \& Im, 2012), and the users become involved in CEB.

Other studies have confirmed that social media allows users to interact and share their experiences, resulting in the generation of e-WOM (Arif et al., 2020; Aslam, Farhat, \& Arif, 2019; Barreda et al., 2015; Yeh \& Choi, 2011). In the past, studies have shown that functional value has an impact on recommendation intentions (Ukpabi, Karjaluoto, Olaleye, \& Mogaji, 2020) and customer satisfaction (An \& Han, 2020), and leads to continued usage intentions (Zhang et al., 2015). Studies related to social media have confirmed that consumers who experience fun and learning are likely to demonstrate CEBs such as advocacy, feedback, and eWom (Carlson et al., 2018; Jahn \& Kunz, 2012; Vries \& Carlson, 2014).

From this discussion, we can establish the hypothesis that brand learning value leads to the development of customer engagement behaviors, which include collaboration, feedback, and mobilizing behaviors. Hence:

$\mathrm{H}_{5}$ : Brand learning value has a positive influence on CEB intentions (feedback, collaboration, and mobilizing intentions).

\subsubsection{Hedonic value and CEB intentions}

Hedonic value is a stimulating factor that results from the fun and excitement gained by individuals when using a brand page (Carlson et al., 2018; Dabbous \& Barakat, 2020) and it works as a key element in the use of a specific brand or platform (An \& Han, 2020).

On a brand page, customers interact with each other, providing them with a source of exciting, amazing, and pleasurable experiences, as connection and interaction are at the core of social media (Arif et al., 2020; Carlson et al., 2016; Zhang et al., 2015). The elements of enjoyment may include the information shared by a user regarding a brand or the marketing activities by brands (Arif et al., 2020; Shi et al., 2016). According to resource exchange theory and the affect theory of social exchange, consumers reciprocate with the firm when they derive benefits from the consumption experience (Verleye et al., 2014).

Hedonic, social, and cognitive benefits are the drivers of customer engagement intentions in virtual communities (Ladhari, 2007; Verhagen, Swen, Feldberg, \& Merikivi, 2015). Ukpabi et al. (2020) stated that pleasure and entertainment (hedonic) lead to WOM intentions. When customers are excited about their participation in brand page activities and gaining information, they manifest positive feelings towards the brand (Gummerus et al., 2012). In line with this, Arif et al. (2020) point to the significant impact of pleasure on engagement.

In short, hedonic value, derived from fun and entertainment, serves to develop a positive attitude towards a brand and influences customers to provide their feedback by writing reviews or filling in survey forms, and to share their experiences with other users, collaborate, and mobilize. Thus:

$\mathrm{H}_{6}$ : Hedonic value has a positive influence on CEB intentions (feedback, collaboration, and mobilizing). 
In light of all the above, Figure 1 presents the proposed research model.

\section{Research Methodology}

\section{I Measurement development}

All the measurement items were adapted from previous studies. The contact quality (CQ) construct was adapted from Carlson et al. (2018) and Zhang et al. (2015); customer contact quality (CCQ) was adapted from Carlson et al. (2018) and O'Cass \& Carlson (2012); brand learning value (BLV) was adapted from Alnawas \& Aburub (2016) and Carlson et al. (2018); hedonic value (HV) was adapted from Alnawas \& Aburub (2016) and Carlson et al. (2018); feedback intention (FI) was adapted from Carlson et al. (2018); collaboration intention (CI) was adapted from Carlson et al. (2018), Fang, Zhao, Wen, \& Wang (2017), and Shi et al. (2016); and, finally, mobilizing intention was adapted from Roy et al. (2018) (see Appendix A).

The CEB intention variable was measured as a second-order construct which included three variables (feedback, collaboration, and mobilizing intention) with reflective measures. The other variables in the model were also measured as reflective constructs using a 5-point Likert scale in which 5 = strongly agree, $4=$ agree, $3=$ neutral, $2=$ disagree, and 1 = strongly disagree.

\subsection{Data collection and sample}

The data were collected through a self-administered survey questionnaire. The questionnaire had two parts. The first part was related to demographic profile and the second part was related to the constructs. The demographic section contained questions related to gender, age, education level, and income.

To examine the CEB intention of the consumers on social media, a purposive sampling technique was used to draw the responses from the target population. The target population of this research was consumers who had purchased their favorite brand in the last four months and were followers of the brand page on social media, i.e. Facebook. Among all the social networking sites, Facebook is considered because of its high popularity and usage (Sproutsocial, 2020). A questionnaire designed on Google Forms was shared with the respondents who had active Facebook accounts. In addition, a few responses were gathered in person on printed copies of the questionnaire.

Before proceeding with the full analysis, a pilot test was conducted by collecting 50 responses from the target audience through Google Forms. The purpose of the pilot test was to ensure the reliability of the instrument used for data collection (Lavrakas, 2008). The reliability was checked by performing a reliability analysis via IBM SPSS 22. The results showed that the reliability (Cronbach's alpha) of all variables was greater than 0.7, as recommended by $\mathrm{Hu}$ and Bentler (1999).

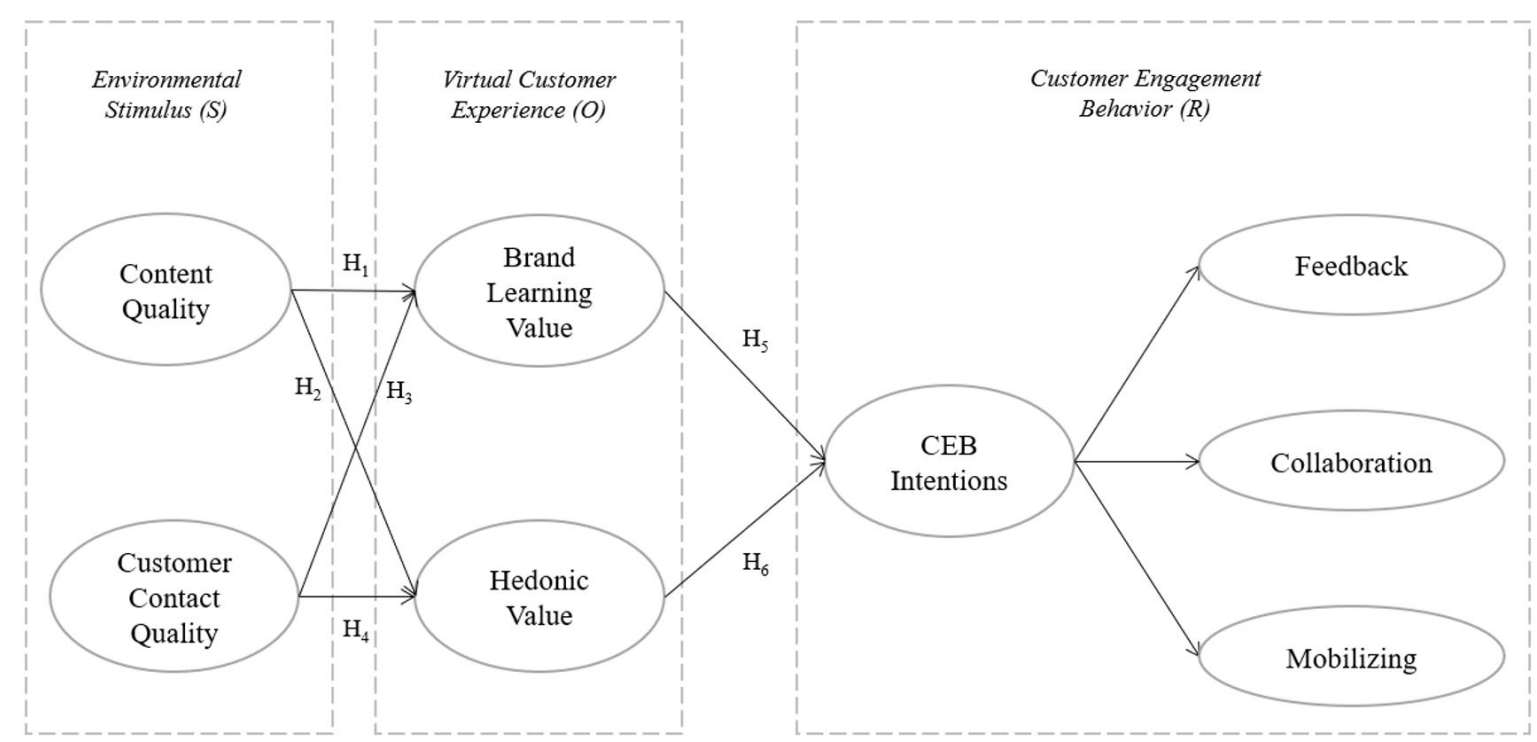

Figure 1. Proposed Research Model

Note. CEB intentions is a multidimensional reflective construct. 
After getting the desired Cronbach's alpha value, the sample data were collected from 250 respondents. Next, a data screening process was undertaken using the collected responses. It showed no issues with missing values; however, 27 outliers were detected. Univariate outliers were identified by means of $\mathrm{z}$-scores, and for multivariate outliers the Mahalanobis distance was used. This reduced the final sample size to 223 responses.

\subsection{Demographic profile}

Table 1 presents the demographic profile of the respondents. Out of 223 respondents, 154 were females and 69 were males. Most of the respondents were in the 18 -25 age group (70.4\%), and $27.7 \%$ belonged to the 26-35 age group.

According to the report by Sproutsocial (2020), females dominate the usage of Facebook (accounting for $75 \%$ of users) and most Facebook users belong to the 18-29 age group (79\%). Also, Napoleoncat (2019) stated that in Pakistan most Facebook users fall within the 18-24 age bracket. Ouellette (2020) also highlighted the fact that females shop more through online platforms and they buy online clothes more than males. Therefore, these could be reasons for the high proportion of female respondents and the high percentage between 18 and 24 years old.

The demographics also highlighted that most of the respondents $(58.7 \%)$ reported a monthly income

\section{Table 1}

\section{Demographic profile of the respondents}

\begin{tabular}{lcc}
\hline & Frequency & $\%$ \\
\hline Gender & 69 & 30.9 \\
Male & 154 & 69.1 \\
Female & & \\
Age & 157 & 70.4 \\
$18-25$ & 62 & 27.8 \\
$26-35$ & 2 & 0.9 \\
36-45 & 2 & 0.9 \\
45 or above & & \\
Education Level & 63 & 28.3 \\
Undergraduate & 107 & 48 \\
Graduate & 53 & 23.8 \\
Postgraduate & & \\
Income Level (PKR) & 131 & 58.7 \\
15001-25000 & 40 & 17.9 \\
25001-35000 & 21 & 9.4 \\
35001-45000 & 31 & 13.9 \\
45001 or above & & \\
\hline
\end{tabular}

between PKR 15001-25000. Moreover, 48\% of the respondents had a bachelor's education.

\subsection{Statistical techniques}

A pilot test was carried out using IBM SPSS 22 and the statistical technique applied to the proposed research model was partial least squares structural equation modeling (PLS-SEM) using SmartPLS 3.2.

A PLS-SEM analysis has several advantages, including a small sample size, and few assumptions about measurement scales and normal distribution (Ahuja \& Thatcher, 2005). In addition, PLS allows the researcher to specify the relationships among constructs and the underlying measures, "which may result in simultaneous analysis of (1) how well the measures relate to each construct (2) and whether the hypothesized relationships at the theoretical level are empirically true" (Chin, 1998). Based on the aforementioned reasons and on the objectives of this investigation, the use of this technique was considered appropriate.

The research model expresses the link between the data observed and the latent variables. The study first examined the reflective measurement for reliability and validity. Then the hypothesized paths were evaluated.

\section{Data Analysis}

\section{I Measurement model}

The measurement model was assessed by following the guidelines of Hair, Hult, Ringle, and Sarstedt (2016). The individual reliability, internal consistency, convergent validity, and discriminant validity were checked, and all criteria meet the values recommended by the literature (see Appendix A).

Individual reliability was measured by the standardized outer loadings of the items, which should be above 0.7 (Fornell \& Larcker, 1981; Hair et al., 2016).

The internal consistency of the constructs was measured through the Cronbach's alpha. According to Cronbach (1951) and Hair et al. (2016), a Cronbach's alpha above 0.7 is considered as excellent.

Convergent validity was assessed using two parameters: average variance extracted (AVE) and composite reliability (CR). According to Hair et al. (2016), in order to achieve convergent validity, the composite reliability value should exceed 0.7 and the AVE should exceed 0.5. 
Lastly, discriminant validity was assessed using the Fornell and Larcker and HTMT criteria. The Fornell and Larcker criterion compares the square root of the AVE with the correlation among the items and it suggests that the square root of the AVE must exceed the correlation between the different pairs of constructs (Chin, 1998; Fornell \& Larcker, 1981). Another criterion used to assess discriminant validity is the HTMT criterion, where the values must be less than the threshold of 0.85 (Clark \& Watson, 1995). Tables 2 and 3 indicate that all the values match both criteria mentioned, confirming that there is discriminant validity.

Also, the overall goodness of fit was verified through the standardized root mean square residual (SRMR) and normed fit index (NFI). The factors provide an acceptable model fit $(\mathrm{SRMR}=0.067$ and $\mathrm{NFI}=0.92)$ since, as recommended by the literature, the SRMR is < 0.08 (Hu \& Bentler, 1999) and the NFI is > 0.9 (Byrne, 2008), respectively.

\subsection{Structural model analysis}

The results of the hypotheses test are presented in Table 4. The results show that content quality has a positive and significant effect on brand learning value $(\mathrm{p}<0.001, \beta=0.396)$ and on hedonic value $(\mathrm{p}<0.01$; $\beta=0.189$ ). Therefore, $H_{1}$ and $H_{2}$ are empirically supported. Additionally, customer contact quality has a positive effect on brand learning value $(\mathrm{p}<0.05, \beta=0.455)$. This is one of the strongest relationships in the model. Therefore, $\mathrm{H}_{3}$ is empirically supported. Customer contact quality did not show a significant effect on hedonic value $(\mathrm{p}=0.072$; $\beta=0.153$ ), which allows us to reject $\mathrm{H}_{4}$. Finally, the results

Table 2

\section{Fornell-Larcker criterion}

\begin{tabular}{cccccccc}
\hline & CQ & CCQ & BLV & HV & FI & CI & MI \\
\hline CQ & $\mathbf{0 . 7 5 8}$ & & & & & & \\
CCQ & 0.465 & $\mathbf{0 . 7 7 9}$ & & & & & \\
BLV & 0.483 & 0.373 & $\mathbf{0 . 8 3 1}$ & & & & \\
HV & 0.295 & 0.257 & 0.423 & $\mathbf{0 . 8 3 4}$ & & & \\
FI & 0.273 & 0.234 & 0.405 & 0.423 & $\mathbf{0 . 8 1 9}$ & & \\
CI & 0.169 & 0.253 & 0.364 & 0.387 & 0.57 & $\mathbf{0 . 7 8 3}$ & \\
MI & 0.229 & 0.215 & 0.325 & 0.378 & 0.523 & 0.676 & $\mathbf{0 . 8}$ \\
\hline
\end{tabular}

Note. Diagonal values are square root of AVE and off-diagonal values are the correlations.

Table 3

Heterotrait monotrait ratio (HTMT)

\begin{tabular}{cccccccc}
\hline & CQ & CCQ & BLV & HV & FI & CI & MI \\
\hline CQ & & & & & & & \\
CCQ & 0.630 & & & & & & \\
BLV & 0.592 & 0.487 & & & & & \\
HV & 0.345 & 0.331 & 0.522 & & & & \\
FI & 0.342 & 0.330 & 0.511 & 0.498 & & & \\
CI & 0.213 & 0.336 & 0.455 & 0.456 & 0.672 & 0.792 & \\
MI & 0.270 & 0.277 & 0.394 & 0.436 & 0.612 & \\
\hline
\end{tabular}

Table 4

Hypothesis testing

\begin{tabular}{lcccc}
\hline \multicolumn{1}{c}{ Path } & Coefficient & T-stats & P & Results \\
\hline Content Quality $\rightarrow$ Brand Learning Value & 0.396 & 6.564 & 0 & Supported \\
Content Quality $\rightarrow$ Hedonic Value & 0.189 & 2.902 & 0.004 & Supported \\
Customer Contact Quality $\rightarrow$ Brand Learning Value & 0.455 & 2.548 & 0.011 & Supported \\
Customer Contact Quality $\rightarrow$ Hedonic Value & 0.153 & 1.803 & 0.072 & Rejected \\
Brand Learning Value $\rightarrow$ Customer Engagement Behavior & 0.282 & 3.800 & 0 & Supported \\
Hedonic Value $\rightarrow$ Customer Engagement Behavior & 0.342 & 5.895 & 0 & Supported \\
\hline
\end{tabular}


confirm that the main factor for customer engagement behavior is hedonic value $(p<0.05, \beta=0.342)$, followed by brand learning value $(\mathrm{p}<0.05, \beta=0.282)$. The results presented for these relationships allow us to accept $\mathrm{H}_{5}$ and $\mathrm{H}_{6}$.

The $\mathrm{R}^{2}$ values determine the proportion of variance of the dependent variables that can be predicted by the independent variables. The stimuli variables, namely content quality and customer contact quality, predict brand learning value by about $26.2 \%$ and hedonic value by about $10.5 \%$. In addition, these variables (hedonic value and brand learning value) also predict customer engagement behavior intentions by about $27.9 \%$.

\section{Conclusion}

This study examined the effect of service-design characteristics of clothing brand social media pages (i.e. content quality and customer contact quality) on customer perceived value (i.e. brand learning value and hedonic value). In the same vein, the study examined the impact of brand learning value and hedonic value on customer engagement behaviors (CEBs): feedback, collaboration, and mobilizing intentions. The study used S-O-R theory to develop the research framework. Content quality and customer contact quality serve as the environmental stimuli, which help in developing customer value perceptions, including brand learning value and hedonic value, which work as the organism, which in turn forms customer engagement behavior as a response.

The results of the study confirm that adequate, relevant, and useful information on a brand page helps followers to learn about the brand. In the past, studies have stated that relevant information benefits the consumer in terms of learning about the brand (Zhang et al., 2015) and supports better engagement with the brand (Islam \& Rahman, 2017). Content quality brings hedonic value, i.e. enjoyment, excitement, and fun. Carlson et al. (2018) found similar results for the impact of content quality on hedonic value in the context of social brand pages. The study of Dabbous and Barakat (2020) also provided evidence of the influencing role of content quality on brand awareness.

During sales promotion activities, brand pages provide customers with useful information about the time and date of sales, and thus brand pages serve as a better medium of information related to brands and their offerings as compared to other sources. In addition, social media has a playful nature that enables its users to not only enhance their knowledge but also gives them a fun and entertaining experience. It is concluded that the content characteristics of social media stimulate value perceptions, including fun and arousal, which lead to participative behavior by customers.

The results also highlight that content quality influences brand learning value more than hedonic value. This contradicts the findings of Dabbous and Barakat (2020), as they revealed that content quality greatly influences hedonic motivation instead of brand awareness.

The results for customer contact quality suggest that it only serves as an environmental stimulus for brand learning value, whereas it is found to be insignificant in the case of hedonic value. This reveals that having a brand page on Facebook involves benefits in terms of creating awareness about the brand and keeping customers informed about the activities of the brand. However, it does not excite or entertain the customer. The positive and significant results for the impact of customer contact quality on brand learning value are similar to in the study of Carlson et al. (2018). However, the findings for customer contact quality and hedonic value are quite surprising. These contradict the findings of Carlson et al. (2018) as they found a significant relationship between them. One possible reason could be that in the clothing sector consumers only feel ease and convenience because of the contact quality as they conveniently access their favorite brand page, and it may be that in this case consumers' hedonic value arises from going to traditional outlets.

Lastly, the results suggest that brand learning value and hedonic value also lead to the development of customer responses in the form of feedback, collaboration, and mobilizing intentions. In other words, both hedonic value and brand learning value develop customer engagement behavior. Previously, Jahn and Kunz (2012) argued that hedonic value boosts usage intention for fan pages and ultimately brings consumer engagement. Fang et al. (2017) identified the positive impact of utilitarian benefit on customer engagement behavioral intention in the context of travel apps. Dabbous and Barakat (2020) also identified positive and significant results for hedonic motives and customer engagement.

The research indicates that users of clothing brand social media pages respond in the form of giving feedback, collaborating, and mobilizing fellow customers. The results of this study suggest that if users get adequate information about the brand and are entertained, this 
multiplies by two-fold the consumer involvement in the social media brand page. Customers usually interact with each other, discuss the features of brands, and give reviews that help the brand improve its services and compete with others. Moreover, these customers can take actions in favor or against the brand in response to its marketing and operational practices. The results also provide the insight that hedonic value appears to strongly contribute to customer engagement behavior.

This research contributes to the relevant literature from different perspectives. First, it examines customer engagement behavior particularly on clothing brand Facebook pages. Second, it advances the findings of Carlson et al. (2018) as it captures an additional aspect of customer engagement behavior by measuring mobilizing intention. Third, it confirms the applicability of S-O-R theory in the context of brand social media webpage engagement. It confirms that online brand page characteristics work as stimuli and drive customer engagement through perceived value.

\section{I Managerial implications and recommendations}

In accordance with the significant results regarding the impact of content quality on brand learning value and hedonic value, it is recommended that clothing brand page managers develop useful informational content for users to enhance the informational value for their customers. Since nowadays people are highly engaged with social media, it is very important how the information on such pages is designed and maintained.

The results highlight the fact that clothing brand pages on social media serve as the means to update consumers about the products offered by the brands and excite the consumer. Therefore, the information must be designed in such a way that influences consumers to engage in positive word-of-mouth about the brand.

The results also reveal that hedonic values are more favorably induced by content quality. This reveals that marketers of clothing brand pages must enhance the quality of the information available on this platform, as available content is a source of fun for users. Brand managers should endeavor to develop activities that engage users with their pages and keep the customer excited.

Considering the results for customer contact quality and brand learning values, it is essential for social media operators to focus on the ease and availability of relevant information for customers because the research indicates that customer contact quality greatly influences value perceptions related to brand learning, unlike content quality. That is, accessibility matters more than quality.

In addition, the results indicate that customer engagement behavior is driven more by hedonic value as compared to brand learning value. This confirms that funrelated activities can play a vital role in the inducement of customer participation on these social media pages. If consumers find hedonic value on brand pages, they are more likely to engage and provide feedback about the brand on social media, which is very important for the brand to improve and compete with others. Also, they are more likely to collaborate and mobilize. Engaged customers serve as a source of marketing for brands, sharing their opinions and recommendations with other customers about the brand.

\subsection{Future lines of research and limitations}

Although this research presented several pieces of useful theoretical and managerial information, it is not free from limitations, which gives rise to the need for new future research. First, the research demonstrates the three drivers of customer engagement behavior, namely feedback, collaboration, and mobilizing intentions. In the future, researchers could further expand the CEB construct by including other dimensions such as influencing, augmenting, etc. Second, the research only addresses engagement with the Facebook brand page of clothing brands; hence the research model could further be tested in other contexts. Third, the research is specific to Facebook and, therefore, future researchers could address engagement in other social media platforms such as Instagram and perform a comparative analysis. Fourth, in this study the data are specific to Karachi; they could be extended to include other cities of the country to draw more holistic results. Similarly, the model could be tested in other countries. Fifth, an analysis of gender could be made in future studies, describing the difference between the behavior of males and females on such brand pages. Sixth, this study focused on only two characteristics of brand pages, hence future researchers could examine other characteristics such as interactivity, sociability, etc. Other aspects of perceived value could be used in future studies, such as social value. 


\section{References}

Ahn, T., Ryu, S., \& Han, I. (2004). The impact of the online and offline features on the user acceptance of Internet shopping malls. Electronic commerce research and applications, 3(4), 405-420.

Alexander, M., Jaakkola, E., Brodie, R. J., \& Hollebeek, L. D. (2015). Customer engagement behaviours and value co-creation. Customer engagement: Contemporary issues and challenges, 3-20.

Alnawas, I., \& Aburub, F. (2016). The effect of benefits generated from interacting with branded mobile apps on consumer satisfaction and purchase intentions. Journal of Retailing and Consumer Services, 3(1), 313-322.

AlphaPro (2018). Pakistan Social Media Stats 2018. Retrieved from https://alphapro.pk/pakistan-socialmedia-stats-2018.

An, M., \& Han, S.-L. (2020). Effects of experiential motivation and customer engagement on customer value creation: Analysis of psychological process in the experience-based retail environment. Journal of Business Research. doi:10.1016/j.jbusres.2020.02.044

Ananda, A. S., Hernández-García, Á., Acquila-Natale, E., \& Lamberti, L. (2019). What makes fashion consumers "click"? Generation of eWoM engagement in social media. Asia Pacific Journal of Marketing and Logistics, 31(2), 398-418.

Argyris, Y. A., Muqaddam, A., \& Liang, Y. (2019). The Role of Flow in Dissemination of Recommendations for Hedonic Products in User-Generated Review Websites. International Journal of Human-Computer Interaction, 36(3), 271-284.

Arif, I., Aslam, W. \& Siddiqui, H. (2020) Influence of brand related user-generated content through Facebook on consumer behaviour: A stimulus-organism-response framework. International Journal of Electronic Business, 15(2).

Aslam, W., Farhat, K., \& Arif, I. (2019). Role of electronic word of mouth on purchase intention. International Journal of Business Information Systems, 30(4), 411-426.
Aslam, W., Ham, M., \& Farhat, K. (2018). Influencing factors of brand perception on consumers' repurchase intention: An examination of online apparel shopping. Management: journal of contemporary management issues, 23(2), 87-102.

Baker, J., Grewal, D. \& Parasuraman, A. (1994). The influence of store environment on quality inferences and store image, Journal of the Academy of Marketing Science, 22(4), 328-339.

Barreda, A. A., Bilgihan, A., Nusair, K., \& Okumus, F. (2015). Generating brand awareness in online social networks. Computers in Human Behavior, 5(2), 600-609. doi:10.1016/j.chb.2015.03.023

Berger, J., \& Milkman, K. L. (2012). What Makes Online Content Viral? Journal of Marketing Research, 49(2), 192-205. doi:10.1509/jmr.10.0353

Bettencourt, L. A. (1997). Customer voluntary performance: Customers as partners in service delivery. Journal of retailing, 73(3), 383.

Bilgihan, A., Kandampully, J., \& Zhang, T. C. (2016). Towards a unified customer experience in online shopping environments. International Journal of Quality and Service Sciences, 8(1), 102-119. doi:10.1108/ijqss-07-2015-0054.

Breidbach, C., Brodie, R., \& Hollebeek, L. (2014). Beyond virtuality: From engagement platforms to engagement ecosystems. Managing Service Quality: An International Journal, 24(6), 592-611.

Bridges, E., \& Florsheim, R. (2008). Hedonic and utilitarian shopping goals: The online experience. Journal of Business research, 61(4), 309-314.

Bui, M. \& Kemp, E. (2013) E-tail emotion regulation: examining online hedonic product purchases, International Journal of Retail \& Distribution Management, 4(2), 155-170.

Business Recorder (2019). The Booming Trend of Online Shopping in Pakistan. Retrieved from https://www. brecorder.com/2019/04/09/487237/the-booming-trendof-online-shopping-in-pakistan/ accessed: 8 April 2020

Byrne, B.M. (2008). Structural Equation Modeling with EQS: Basic Concepts, Applications, and Programming. New York, NY: Psychology Press. 
Cachero-Martínez, S., \& Vázquez-Casielles, R. (2017). Living positive experiences in store: how it influences shopping experience value and satisfaction?. Journal of Business Economics and Management, 18(3), 537-553.

Carlson, J., Rahman, M., Rosenberger, P., \& Holzmüller, H. (2016), Understanding communal and individual customer experiences in group-oriented event tourism: an activity theory perspective. Journal of Marketing Management, 32(9/10), 900-925.

Carlson, J., Rahman, M., Voola, R., \& De Vries, N. (2018). Customer engagement behaviours in social media: capturing innovation opportunities. Journal of Services Marketing, 32(1), 83-94. doi:10.1108/jsm-02-2017-0059

Casaló, L. V., Flavián, C., \& Ibáñez-Sánchez, S. (in press). Be creative, my friend! Engaging users on Instagram by promoting positive emotions. Journal of Business Research.

Cengiz, H. (2017). Effect of the need for popularity on purchase decision involvement and impulse-buying behavior concerning fashion clothing. Journal of Global Fashion Marketing, 8(2), 113-124.

Chen, C. C., \& Yao, J. Y. (2018). What drives impulse buying behaviors in a mobile auction? The perspective of the Stimulus-Organism-Response model. Telematics and Informatics, 35(5), 1249-1262.

Chin, W. W. (1998). Commentary: Issues and opinion on structural equation modeling. MIS Quarterly, 22(1), 7-16.

Chiu, C.-M., Huang, H.-Y., \& Yen, C.-H. (2010). Antecedents of trust in online auctions. Electronic Commerce Research and Applications, 9(2), 148-159. https://doi.org/ https://doi.org/10.1016/j.elerap.2009.04.003

Clark, L. A., \& Watson, D. (1995). Constructing validity: Basic issues in objective scale development. Psychological Assessment, 7(3), 309-319. doi:10.1037/1040-3590.7.3.309

Cronbach, L. J. (1951). Coefficient alpha and the internal structure of tests. Psychometrika, 16(3), 297-334.

Cvijikj, I. P., \& Michahelles, F. (September, 2011). Understanding social media marketing: A case study on topics, categories and sentiment on a Facebook brand page. International academic MindTrek conference: Envisioning future media environments, Tampere, Finland,
15. Retrieved from https://www.researchgate.net/ publication/254008127_Understanding_social_media_ marketing_A_case_study_on_topics_categories_and_ sentiment_on_a_Facebook_brand_page

Dabbous, A., \& Barakat, K. A. (2020). Bridging the online offline gap: Assessing the impact of brands' social network content quality on brand awareness and purchase intention. Journal of Retailing and Consumer Services, 53, 101966

Daugherty, T., Eastin, M. S., \& Bright, L. (2008). Exploring consumer motivations for creating user-generated content. Journal of Interactive Advertising, 8(2), 16-25. doi:10.10 80/15252019.2008.10722139

Dholakia, U. M., Blazevic, V., Wiertz, C., \& Algesheimer, R. (2009). Communal service delivery: How customers benefit from participation in firm-hosted virtual P3 communities. Journal of Service Research, 12(2), 208-226.

Eastman, J. K., Iyer, R., \& Randall, C. (2009). Understanding internet shoppers: an exploratory study. Marketing Management Journal, 19(2), 104-117.

Eroglu, S. A., Machleit, K. A., \& Davis, L. M. (2003). Empirical testing of a model of online store atmospherics and shopper responses. Psychology and Marketing, 20(2), 139-150. doi:10.1002/mar.10064

Facebook for Business (2017). Facebook, Instagram and the changing world of fashion shopping. Retrieved from https://www.facebook.com/business/news/insights/facebookinstagram-and-the-changing-world-of-fashion-shopping.

Fang, J., Zhao, Z., Wen, C., \& Wang, R. (2017). Design and performance attributes driving mobile travel application engagement. International Journal of Information Management, 37(4), 269-283. doi:10.1016/j. ijinfomgt.2017.03.003

Fornell, C. R. \& Larcker, D. F. (1981). Evaluating structural equation models with unobservable variables and measurement error. Journal of Marketing Research, 18(3), 375-381.

Gironda, J. T., \& Korgaonkar, P. K. (2014). Understanding consumers' social networking site usage. Journal of 
Marketing Management, 30(5-6), 571-605. doi:10.108 0/0267257x.2013.851106

Groeger, L., Moroko, L., \& Hollebeek, L. D. (2016). Capturing value from non-paying consumers' engagement behaviours: Field evidence and development of a theoretical model. Journal of Strategic Marketing, 24(3-4), 190-209. doi:10.1080/0965254x.2015.1095223

Gruner, R., Homburg, C. \& Lukas, B. (2014). Firm-hosted online brand communities and new product success. Journal of the Academy of Marketing Science, 42(1), 29-48.

Gummerus, J., Liljander, V., Weman, E., \& Pihlström, M. (2012). Customer engagement in a Facebook brand community. Management Research Review, 35(9), 857-877. doi:10.1108/01409171211256578

Ha, Y. \& Im, H. (2012). Role of web site design quality in satisfaction and word of mouth generation. Journal of Service Management, 23(1), 79-96.

Hair, J., Hult, G., Ringle, C., \& Sarstedt, M. (2016), A Primer on Partial Least Squares Structural Equation Modeling. Los Angeles, CA: Sage Publications.

Hamilton, M., Kaltcheva, V., \& Rohm, A. (2016), Social media and value creation: The role of interaction satisfaction and interaction immersion. Journal of Interactive Marketing, 36, 121-133.

Ho, C. W., \& Wang, Y. B. (2015). Re-purchase intentions and virtual customer relationships on social media brand community. Human-centric computing and information sciences, 5(1), 18.

Hollebeek, L., Srivastava, R. \& Chen, T. (2016). S-D logicinformed customer engagement: integrative framework, revised fundamental propositions, and application to CRM. Journal of the Academy of Marketing Science, 47, 161-185.

Hu, L. T., \& Bentler, P. M. (1999). Cutoff criteria for fit indexes in covariance structure analysis: Conventional criteria versus new alternatives. Structural equation modeling: a multidisciplinary journal, 6(1), 1-55.

Hudson, S., Huang, L., Roth, M. S., \& Madden, T. J. (2016). The influence of social media interactions on consumer-brand relationships: A three-country study of brand perceptions and marketing behaviors. International Journal of Research in Marketing, 33(1), 27-41. doi:10.1016/j.ijresmar.2015.06.004

Internet world stats (2017), Internet Usage in Asia. Retrieved from https://www.internetworldstats.com/ stats3.htm

Islam, J. U., \& Rahman, Z. (2017). The impact of online brand community characteristics on customer engagement: An application of Stimulus-Organism-Response paradigm. Telematics and Informatics, 34(4), 96-109.

Jaakkola, E., \& Alexander, M. (2014), The role of customer engagement behavior in value co-creation. Journal of Service Research, 17(3), 247-261.

Jahn, B., \& Kunz, W. (2012). How to transform consumers into fans of your Brand. Journal of Service Management, 23(3), 344-361.

Jiang, Z., Chan, J., Tan, B. C., \& Chua, W. S. (2010). Effects of interactivity on website involvement and purchase intention. Journal of the Association for Information Systems, 11(1), 34-46.

Kao, T., Yang, M., Wu, J. \& Cheng, Y. (2016), Co-creating value with consumers through social media. Journal of Services Marketing, 30(2), 141-151.

Kim, A. J., \& Johnson, K. K. P. (2016). Power of consumers using social media: Examining the influences of brand-related user-generated content on Facebook. Computers in Human Behavior, 58, 98-108. doi:10.1016/j. chb.2015.12.047

Kim, C., Galliers, R. D., Shin, N., Ryoo, J. H., \& Kim, J. (2012). Factors influencing internet shopping value and customer repurchase intention. Electronic Commerce Research and Applications, 11(4), 374-387.

Kim, K. H., Ko, E., Xu, B., \& Han, Y. (2012). Increasing customer equity of luxury fashion brands through nurturing consumer attitude. Journal of Business Research, 65(10), 1495-1499.

Kohler, T., Fueller, J., Matzler, K., Stieger, D., \& Füller, J. (2011). Co-creation in virtual worlds: The design of the user experience. MIS quarterly, 35(3), 773-788. 
Koufaris, M. (2002). Applying the technology acceptance model and flow theory to online consumer behavior. Information Systems Research, 13(2), 205-223. doi:10.1287/ isre.13.2.205.83

Kwak, K. T., Choi, S. K., \& Lee, B. G. (2014). SNS flow, SNS self-disclosure and post hoc interpersonal relations change: Focused on Korean Facebook user. Computers in Human Behavior, 31, 294-304. doi:10.1016/j. chb.2013.10.046

Ladhari, R. (2007). The effect of consumption emotions on satisfaction and word-of-mouth communications. Psychology and Marketing, 24(12), 1085-1108. doi:10.1002/ mar.20195

Lavrakas, P. J. (2008). Encyclopedia of survey research methods. Sage Publications.

Liu, M., \& Xiao, Y. (2008). Reach on relationship between consumer satisfaction and web consumer shopping behavior. International Journal of Business Research, 8(5), 127-135.

Liu, W., Guo, F., Ye, G., \& Liang, X. (2016). How homepage aesthetic design influences users' satisfaction: Evidence from China. Displays, 42, 25-35.

Liu, Y., Li, H., \& Hu, F. (2013). Website attributes in urging online impulse purchase: An empirical investigation on consumer perceptions. Decision Support Systems, 55(3), 829-837.

Lu, H. P., \& Su, P. Y. J. (2009). Factors affecting purchase intention on mobile shopping web sites. Internet Research, 19(4), 442-458.

Mega Marketing (2018). Social Media Marketing in Pakistan. Retrieved from http://megamarketingnetwork. com/social-media-marketing-pakistan/

Mehrabian, A., \& Russell, J. (1974). An Approach to Environmental Psychology. Cambridge, MA: MIT Press.

Muniz, A. M., \& O'guinn, T. C. (2001). Brand community. Journal of consumer research, 27(4), 412-432.

Nambisan, S., \& Baron, R. (2009). Virtual customer environments: testing a model of voluntary participation in value co-creation activities. Journal of Product Innovation Management, 26(4), 388-406.
Nambisan, S., \& Nambisan, P. (2008). How to profit from a better 'virtual customer environment'. MIT Sloan management review, 49(3), 53.

Napoleoncat (2019). Facebook users in Pakistan. Available at: https://napoleoncat.com/stats/facebook-users-inpakistan/2019/03 (accessed 30 March 2020)

Nicolaou, A. I., \& McKnight, D. H. (2006). Perceived information quality in data exchanges: Effects on risk, trust, and intention to use. Information Systems Research, $17(4), 332-351$.

O'Cass, A., \& Carlson, J. (2012). An empirical assessment of consumers' evaluations of web site service quality: Conceptualizing and testing a formative model. Journal of Services Marketing, 26(6), 419-434.

O'Connell, Liam (2020). Market value of global apparel demand from 2005 to 2020 . Retrieved from https:// www.statista.com/statistics/821415/value-of-the-globalapparel-market/

Ouellette, C. (2020). Online Shopping Statistics You Need to Know in 2020. Retrieved from https://optinmonster. com/online-shopping-statistics/

Overby, J. W., \& Lee, E. J. (2006). The effects of utilitarian and hedonic online shopping value on consumer preference and intentions. Journal of Business Research, 59(10-11), 1160-1166.

Park, J., Han, H., \& Park, J. (2013). Psychological antecedents and risk on attitudes toward e-customization. Journal of Business Research, 66(12), 2552-2559.

Park, J., Stoel, L., \& Lennon, S. J. (2008). Cognitive, affective and conative responses to visual simulation: The effects of rotation in online product presentation. Journal of Consumer Behaviour: An International Research Review, 7(1), 72-87

Pebrianti, W. (2016). Web attractiveness, hedonic shopping value and online buying decision. International Journal of Economics and Management, 10, 123-134.

Peng, C., \& Kim, G. Y. (2014). Application of the stimuliorganism-response (S-O-R) framework to online shopping behaviour. Journal of Internet Commerce, 13(3/4), 159-176. 
Ramaswamy, V. (2009). Leading the transformation to cocreation of value. Strategy \& Leadership, 37(2), pp. 32-37.

Roberts, D., \& Piller, F. (2016). Finding the right role for social media in innovation. MIT Sloan Management Review, 57(3), 41.

Roy, A. (2018). 7 Tips to Market Your Brand Using Customer Reviews. Retrieved from https://www.jeffbullas. com/author/ankit-roy/

Roy, S. K., Balaji, M. S., Soutar, G., Lassar, W. M., \& Roy, R. (2018). Customer engagement behavior in individualistic and collectivistic markets. Journal of Business Research, 8(6), 281-290.

Shi, S., Chen, Y., \& Chow, W. S. (2016). Key values driving continued interaction on brand pages in social media: An examination across genders. Computers in Human Behavior, 6(2), 578-589.

Sorce, P., Perotti, V., \& Widrick, S. (2005). Attitude and age differences in online buying. International Journal of Retail \& Distribution Management, 33(2), 122-132.

Sproutsocial (2020). Social media demographics to inform your brand's strategy in 2020. Retrieved from https://sproutsocial.com/insights/new-social-mediademographics/\#FB-demos

Statista (2020). Global digital population as of January 2020. Retrieved from https://www.statista.com/statistics/617136/ digital-population-worldwide/

Stewart, D. W., \& Pavlou, P. A. (2002). From consumer response to active consumer: Measuring the effectiveness of interactive media. Journal of the Academy of Marketing Science, 30(4), 376-396. doi:10.1177/009207002236912

Thongmak, M. (2015, June). Engaging Facebook users in brand pages: Different posts of marketing-mix information. International Conference on Business Information Systems, Springer, Cham, 208.

Tsao, W. C., Hsieh, M. T., \& Lin, T. M. (2016). Intensifying online loyalty! The power of website quality and the perceived value of consumer/seller relationship. Industrial Management \& Data Systems, 116(9), 1987-2010.
Tuten, T. L. (2008). Advertising 2.0: Social media marketing in a web 2.0 world: Social media marketing in a web 2.0 world. Retrieved from https://publisher.abc-clio. com/9780313352973

Ukpabi, D. C., Karjaluoto, H., Olaleye, S., \& Mogaji, E. (January 08-10, 2020). Customer value framework and recommendation intention: The moderating role of customer characteristics in an online travel community. Proceedings of the Information and Communication Technologies in Tourism United Kingdom, Great Britain.

Uncles, M., \& Ngo, L. (2017). Introduction to the special issue: Harnessing the power of Brand and co-created innovation. Journal of Brand Management, 24(4), 307-309.

Van Doorn, J., Lemon, K. N., Mittal, V., Nass, S., Pick, D., Pirner, P., ... Verhoef, P. C. (2010). Customer engagement behavior: Theoretical foundations and research directions. Journal of Service Research, 13(3), 253-266. doi:10.1177/1094670510375599

Verhagen, T., \& van Dolen, W. (2011). The influence of online store beliefs on consumer online impulse buying: A model and empirical application. Information \& Management, 48(8), 320-327.

Verhagen, T., Swen, E., Feldberg, F., \& Merikivi, J. (2015). Benefitting from virtual customer environments: An empirical study of customer engagement. Computers in Human Behavior, 4(8), 340-357. doi:10.1016/j. chb.2015.01.061

Verleye, K., Gemmel, P., \& Rangarajan, D. (2014). Managing engagement behaviors in a network of customers and stakeholders: Evidence from the nursing home sector. Journal of Service Research, 17(1), 68-84.

Vries, N. J., \& Carlson, J. (2014). Examining the drivers and brand performance implications of customer engagement with brands in the social media environment. Journal of Brand Management, 21(6), 495-515.

We are social (2020). Digital 2020 Global Overview Report. Retrieved from https://wearesocial.com/blog/2020/01/ digital-2020-3-8-billion-people-use-social-media

Yeh, Y. -H., \& Choi, S. M. (2011). MINI-lovers, maxi-mouths: An investigation of antecedents to 
eWOM intention among brand community members. Journal of Marketing Communications, 17(3), 145-162. doi:10.1080/13527260903351119

Zaglia, M. E. (2013). Brand communities embedded in social networks. Journal of Business Research, 66(2), 216-223. doi:10.1016/j.jbusres.2012.07.015

Zhang, H., Lu, Y., Gupta, S., \& Zhao, L. (2014). What motivates customers to participate in social commerce? The impact of technological environments and virtual customer experiences. Information \& Management, 51(8), 1017-1030.

Zhang, H., Lu, Y., Wang, B., \& Wu, S. (2015). The impacts of technological environments and co-creation experiences on customer participation. Information \& Management, 52(4), 468-482. doi:10.1016/j.im.2015.01.008

Zhang, K. Z. K., \& Benyoucef, M. (2016). Consumer behavior in social commerce: A literature review. Decision Support Systems, 8(6), 95-108. doi:10.1016/j.dss.2016.04.001

Zhang, W., \& Watts, S. A. (2008). Capitalizing on content: Information adoption in two online communities. Journal of the Association for Information Systems, 9(2), 73.

Zhu, D. H., Chang, Y. P., \& Luo, J. J. (2016). Understanding the influence of $\mathrm{C} 2 \mathrm{C}$ communication on purchase decision in online communities from a perspective of information adoption model. Telematics and Informatics, 33(1), 8-16. 


\section{Appendix A}

\section{Standardized Outer Loadings}

\begin{tabular}{|c|c|c|}
\hline Items & $\begin{array}{l}\text { Factor } \\
\text { Loadings }\end{array}$ & Adapted Source \\
\hline \multicolumn{3}{|l|}{ Content quality (CQ) Cronbach's $A l p h a=0.816, C R=0.871, A V E=0.574$} \\
\hline I find the information on this brand page to be valuable. & 0.742 & \multirow{3}{*}{ Carlson et al. (2018) } \\
\hline I think this brand page is a helpful resource. & 0.746 & \\
\hline There is useful information on this brand page. & 0.808 & \\
\hline The information on this page is effective. & 0.768 & \multirow{2}{*}{ Zhang et al. (2015) } \\
\hline This brand page adequately meets my information needs. & 0.722 & \\
\hline \multicolumn{3}{|l|}{ Customer Contact Quality (CCQ) Cronbach's $A l p h a=0.712, C R=0.822, A V E=0.607$} \\
\hline $\begin{array}{l}\text { It is easier to use this brand page for accessing brand-related information than other channels (e.g. } \\
\text { visiting the store, advertising, websites or other social platforms). }\end{array}$ & 0.715 & \multirow{3}{*}{$\begin{array}{c}\text { Carlson et al. (2018); } \\
\text { O'Cass and Carlson } \\
\text { (2012) }\end{array}$} \\
\hline Using this brand page is easier than using other channels to stay up-to-date about the brand. & 0.776 & \\
\hline This brand page is a better alternative to using other ways for getting information. & 0.842 & \\
\hline \multicolumn{3}{|l|}{ Brand Learning Value (BLV) Cronbach's $A l p h a=0.775, C R=0.870, A V E=0.690$} \\
\hline The brand page helps me to obtain solutions to specific brand-related problems that I have. & 0.839 & Carlson et al. (2018) \\
\hline This brand page provides me with information that helps me make important decisions. & 0.854 & \multirow{2}{*}{$\begin{array}{l}\text { Alnawas and Aburub } \\
(2016)\end{array}$} \\
\hline This brand page helps me better manage my money. & 0.798 & \\
\hline \multicolumn{3}{|l|}{ Hedonic Value (HV) Cronbach's $A l p h a=0.853, C R=0.901, A V E=0.696$} \\
\hline The brand page is fun. & 0.836 & \multirow{3}{*}{ Carlson et al., (2018) } \\
\hline The brand page is exciting. & 0.875 & \\
\hline The brand page is entertaining. & 0.854 & \\
\hline Using this brand page improves my mood and makes me happier. & 0.767 & $\begin{array}{c}\text { Alnawas and Aburub } \\
(2016)\end{array}$ \\
\hline \multicolumn{3}{|l|}{ Feedback Intention (FI) Cronbach's $A l p h a=0.836, C R=0.890, A V E=0.670$} \\
\hline When I experience a problem with the brand, I tend to notify the brand page. & 0.753 & \multirow{4}{*}{$\begin{array}{l}\text { Carlson et al. (2018); } \\
\text { Hamilton et al. } \\
\text { (2016) }\end{array}$} \\
\hline $\begin{array}{l}\text { When I have a useful idea on how to improve the brand, I tend to communicate it on the brand } \\
\text { page. }\end{array}$ & 0.843 & \\
\hline I am willing to complete a survey/provide feedback on this brand page. & 0.825 & \\
\hline I tend to provide constructive suggestions to the brand via the brand page on how to improve it. & 0.849 & \\
\hline \multicolumn{3}{|l|}{ Collaboration Intention (CI) Cronbach's Alpha $=0.841, C R=0.888, A V E=0.613$} \\
\hline I tend to share my ideas about the brand with other community users. & 0.772 & \multirow{3}{*}{ Carlson et al. (2018) } \\
\hline I tend to help other community users with brand issues. & 0.824 & \\
\hline I tend to get help from other community users. & 0.825 & \\
\hline I am willing to support other members on this brand page. & 0.756 & Fang et al. (2017) \\
\hline On this brand page, I can provide information to other users. & 0.733 & Shi et al. (2016) \\
\hline \multicolumn{3}{|l|}{ Mobilizing intention (MI) Cronbach's Alpha $=0.860, C R=0.899, A V E=0.640$} \\
\hline I assist other customers if they need my help. & 0.821 & \multirow{5}{*}{ Roy et al. (2018) } \\
\hline I give advice to other customers regarding the services of the brand. & 0.809 & \\
\hline I help other customers if they seem to have problems. & 0.819 & \\
\hline I am willing to take a stand to protect the reputation of the brand. & 0.775 & \\
\hline I am willing to clarify other customers' or outsiders' misunderstandings regarding the brand. & 0.776 & \\
\hline
\end{tabular}




\section{Conflicts of interest:}

The authors have no conflict of interest to declare

\section{Copyrights:}

RBGN owns the copyrights of this published content

\section{Plagiarism analysis}

RBGN performs plagiarism analysis on all its articles at the time of submission and after approval of the manuscript using the iThenticate tool.

\section{Authors:}

1. Wajeeha Aslam, PhD scholar, University of Karachi, Karachi -Pakistan.

Email: Wajeeha_aslam_87@live.com

2. Iviane Ramos de Luna, PhD in Business and Economic Science, University of Granada, Granada, Spain.

Email: iramosde@uoc.edu

\section{Contribution of each author}

1. Wajeeha Aslam: Definition of research problem, development of hypotheses or research questions (empirical studies); Theoretical foundation/literature review, definition of methodological procedures; Data collection: Statistical analysis; Analysis and interpretation of data; Manuscript writing.

2. Iviane Ramos de Luna: Definition of research problem; Development of hypotheses or research questions (empirical studies), theoretical foundation/literature review, statistical analysis, analysis and interpretation of data, Manuscript writing. 